\title{
Extensional shear zones as imaged by reflection seismic lines: the Larderello geothermal field (central Italy)
}

\author{
Andrea Brogi ${ }^{\mathrm{a}, *}$, Antonio Lazzarotto ${ }^{\mathrm{a}}$, Domenico Liotta ${ }^{\mathrm{b}}$, Giorgio Ranalli ${ }^{\mathrm{c}}$ \\ ${ }^{a}$ Dipartimento di Scienze della Terra, Università di Siena, Via Laterina 8, Siena 53100, Italy \\ ${ }^{\mathrm{b}}$ Dipartimento di Geologia e Geofisica, Università di Bari, Via Orabona 4, Bari 70125, Italy \\ ${ }^{\mathrm{c}}$ Department of Earth Sciences and Ottawa-Carleton Geoscience Centre, Carleton University, Ottawa, Canada K1S 5B6
}

Received 15 November 2001; accepted 27 November 2002

\begin{abstract}
The Larderello geothermal field is located in the Inner Northern Apennines, in an area which has been subject to extension since the Early Miocene. The latest extensional episode (Pliocene-Present) has resulted in the formation of NW-trending, NEdipping listric normal faults, whose geometry is controlled down to $\sim 3 \mathrm{~km}$ by borehole data. In this paper, we integrate a new interpretation of seismic reflection lines with existing seismic, field, and borehole data to analyse the relations among listric normal faults, the top of the brittle-ductile transition, and the migration of geothermal fluids.

In accordance with previous interpretations, we consider the strong reflector (K-horizon) marking the top of the reflective mid-lower crust, and located at a depth of 3-5 km in the geothermal area, to represent the top of the brittle-ductile transition. Its reflectivity most probably derives from the presence of overpressured fluids. We identify three main NW-trending, NEdipping extensional brittle shear zones, showing listric geometry and soling out in the vicinity of the K-horizon. The latter appears to be dislocated in correspondence of the soling out of the shear zones. These shear zones, because of the associated intense fracturing, represent the most natural channels of upward migration of geothermal fluids from the magmatic sources located below the K-horizon.

We suggest that these two conclusions - that listric normal faults root at or near the brittle-ductile transition, and that they act as preferential upward migration paths for magmatic fluids - may be of general validity for geothermal fields located in extensional settings.
\end{abstract}

(C) 2002 Elsevier Science B.V. All rights reserved.

Keywords: Reflection seismology; Extensional tectonics; Larderello geothermal area

\section{Introduction}

Reflection seismic surveys have shown that thinned continental crust is often characterized by listric normal faults (Bally et al., 1981). Some listric

* Corresponding author. Fax: +39-5-772-33938.

E-mail address: brogiandrea@unisi.it (A. Brogi). faults are restricted to the sedimentary cover whereas others affect the basement rocks. In the latter case, listric normal faults tend to flatten in the proximity of the brittle-ductile transition (Shelton, 1984; Hamilton, 1987). In principle, the brittle-ductile transition is not detectable by means of seismic reflection surveys. However, in those regions affected by extensional tectonics and high surface heat flow, the high 
reflectivity of the middle-lower crust is usually considered to be a consequence of its ductile behaviour during extension (Blundell, 1990 and references therein). The top of the reflective zone is generally located at about 6-7 s two-way travel time (hereafter: TWT), corresponding to $15 \pm 5 \mathrm{~km}$ (e.g., North Sea province: Klemperer and Hobbs, 1991; Rhine Graben: Mayer et al., 1997; Western United States: McCarthy and Thompson, 1988; Inner Northern Apennines: Decandia et al., 1998). The top of the reflective zone tends to be shallower beneath regions with higher heat flow (Klemperer, 1987). This trend parallels that of the depth of the brittle-ductile transition, which decreases with increasing geothermal gradient (Kusznir and Park, 1987; Ranalli, 1995; Ranalli and Murphy, 1987).

The Larderello geothermal area (Fig. 1) is located in a structural high within the Inner Northern Apennines, which have been affected by extension since Early-Middle Miocene (Carmignani and Kligfield, 1990; Jolivet et al., 1990). Heat flow is very high $\left(120 \mathrm{~mW} / \mathrm{m}^{2}\right.$ as a regional average, with local peaks up to $1000 \mathrm{~mW} / \mathrm{m}^{2}$ : Mongelli et al., 1989). The top of the reflective mid-lower crust is marked by a strong

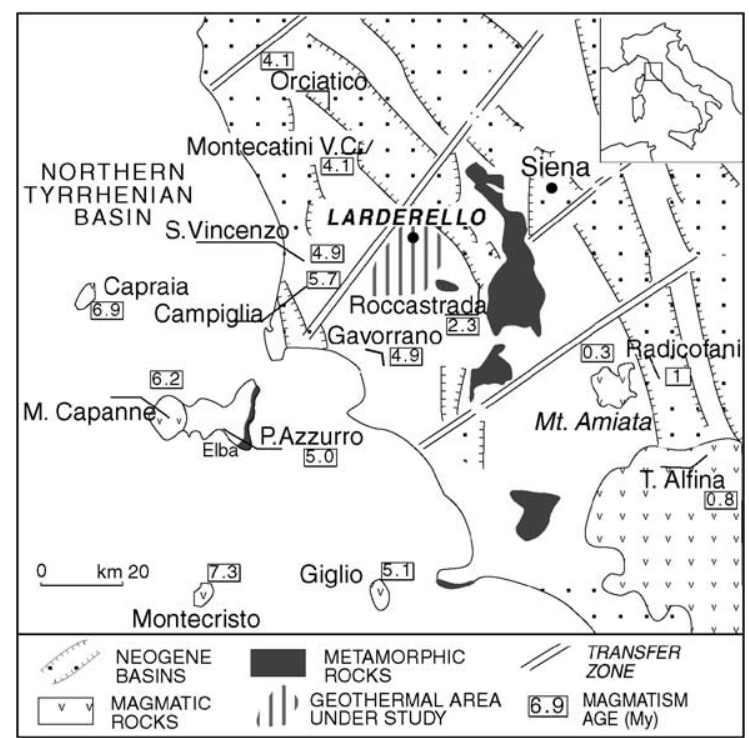

Fig. 1. Simplified structural map of southern Tuscany showing the main extensional structures, the ages of the main magmatic bodies, and the Larderello geothermal area. Miocene and Pliocene transfer zones correspond to transverse shear zones coeval with extensional faults. seismic reflector, named the K-horizon (Batini et al., 1978), located from ca. 1.5 to $4 \mathrm{~s}$ TWT (Cameli et al., 1998 and references therein), corresponding to about 3-6 km of depth (Batini et al., 1983, 1985). These values are consistent with the expected depth of the top of the brittle-ductile transition (Liotta and Ranalli, 1999).

In this paper, we integrate field and borehole data with a new interpretation of reflection seismic lines in order to investigate the relationship between normal faults and the top of the brittle-ductile transition in the Larderello geothermal area. The results allow the identification of three main extensional listric shear zones, which sole out at or just below the K-horizon and are associated with interruptions in its reflectivity. These shear zones represent the most natural pathways for the upward migration of geothermal fluids of deeper magmatic origin.

\section{Geological framework}

After the convergent and collisional stages (Late Cretaceous-Early Miocene), which determined the structural emplacement of the Northern Apennines tectonic units, extensional tectonics (MiocenePresent) affected the Inner Northern Apennines (Decandia et al., 1998 and references therein). Collisional and extensional processes are expressed in the structure of the Larderello geothermal field. A geological map of the area is given in Fig. 2. Three regional tectono-stratigraphic elements have been recognised (Fig. 3): (1) Miocene-Pliocene and Quaternary sediments, filling extensional tectonic depressions and unconformably overlying the substratum (e.g., the Serrazzano and Pomarance Basins); (2) the Ligurian Complex, composed of remnants of Jurassic oceanic crust and its Cretaceous-Oligocene sedimentary cover; this complex was thrust eastward over the Tuscan Complex during Late Oligocene-Early Miocene; and (3) the Tuscan Complex, including sedimentary rocks ranging from Late Triassic evaporites to Late Oligocene-Early Miocene turbidites.

The substratum of the sedimentary cover is mainly known in the area through drilling of geothermal wells, penetrating the crust down to about $3.5 \mathrm{~km}$. It is composed of two units (Bertini et al., 1991): the upper Monticiano-Roccastrada Unit and the lower 


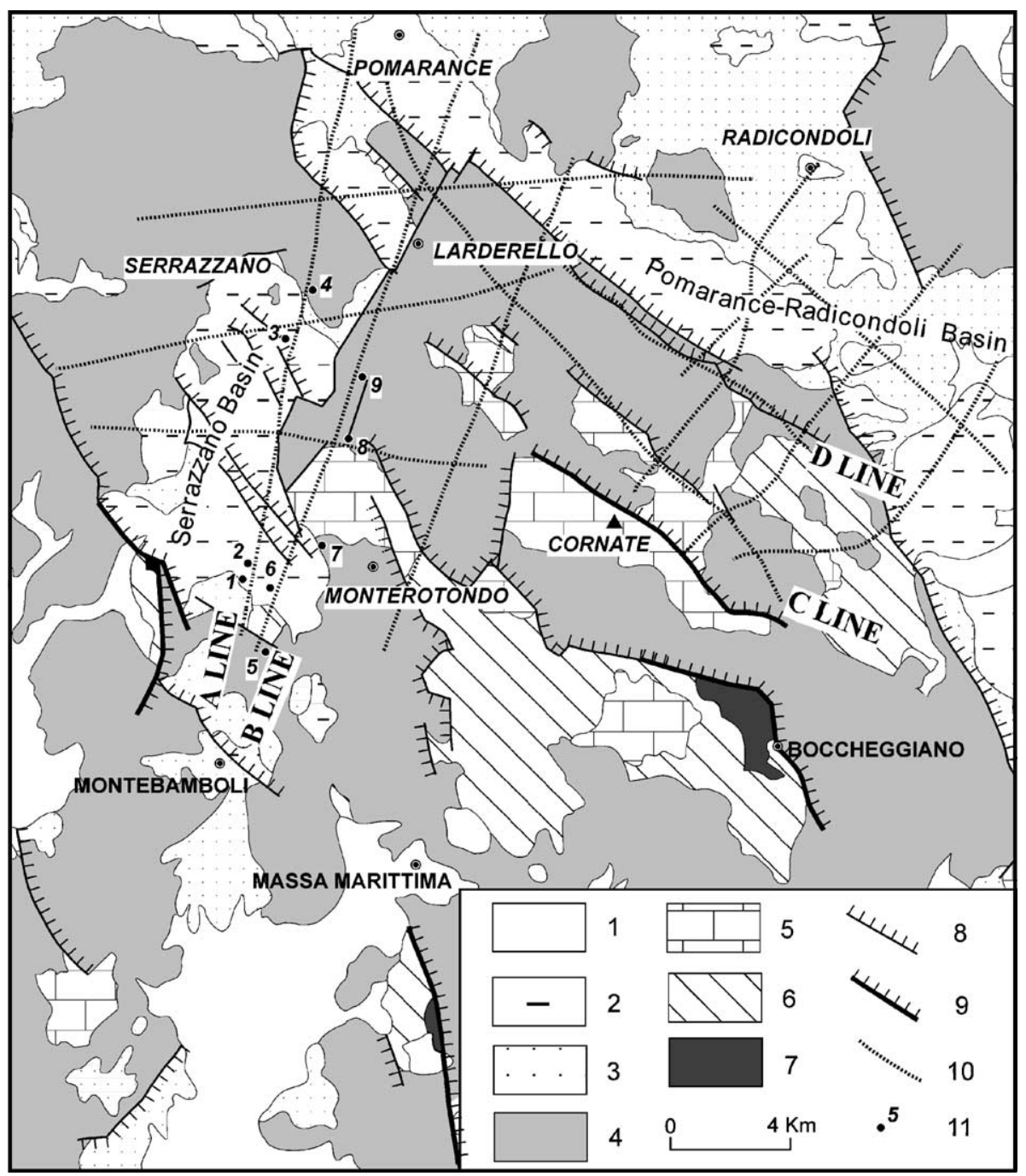

Fig. 2. Geological sketch map of the Larderello area. Traces of the analysed reflection lines are shown by dotted lines. Lines A and B are shown in Figs. 4-7. Parts of lines C and D are shown in Fig. 8. Key: (1) Quaternary continental sediments; (2) Pliocene marine sediments; (3) Miocene continental, brackish, and marine sediments; (4) Ligurian Complex (Jurassic-Oligocene); (5) Tuscan Complex: Late Triassic-Early Miocene sedimentary sequence; (6) Tuscan Complex: late Triassic basal evaporite; (7) Paleozoic phyllite; (8) normal faults; (9) mineralized normal faults; (10) trace of seismic lines (from Cameli et al., 2000); (11) location of boreholes (Lazzarotto, 1967; Franceschini, 1994; Cameli et al., 2000).

Gneiss Complex. The Monticiano-Roccastrada Unit consists of three metamorphic groups (see Fig. 3), which were affected by Apennine greenschist metamorphism. The effects of the Apennine orogeny are not recorded in the Gneiss Complex (Elter and Pandeli, 1990), which may correspond to part of the Apennine foreland crust (Bertini et al., 1991). In the Gneiss Complex, and in the micaschists and phyllites of the Monticiano-Roccastrada Unit, a later high- temperature/low-pressure metamorphism was superimposed over previous mineral associations (Villa and Puxeddu, 1994).

After the emplacement of the Monticiano-Roccastrada Unit (Late Oligocene-Early Miocene), three extensional tectonic events affected the Larderello area (Baldi et al., 1994; Dallmeyer and Liotta, 1998). The first event caused the juxtaposition of the Ligurian Units and Late Triassic evaporites along 


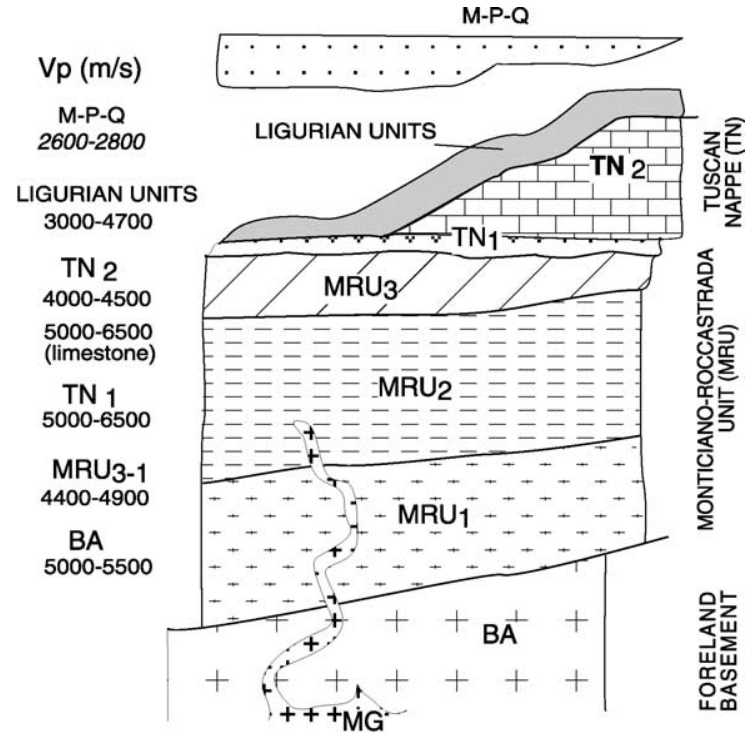

Fig. 3. Tectono-stratigraphic units recognised in the Larderello area: MPQ - Quaternary, Pliocene, and Miocene sediments; Tuscan Nappe (TN): $\mathrm{TN}_{2}$-Early Miocene-Rhetic sequence; $\mathrm{TN}_{1}$ - Late Triassic evaporites; Monticiano-Roccastrada Unit (MRU): $\mathrm{MRU}_{3}$ Mesozoic-Paleozoic Group, made up of dolostones and limestones (Late Triassic), quartz meta-conglomerates, quartzites, and phyllites (Verrucano Group, Middle-Early Triassic), sandstones, phyllites (Middle-Late Carboniferous-Early Permian); $\mathrm{MRU}_{2}$-PhylliticQuartzitic Group; $\mathrm{MRU}_{1}$-Paleozoic Micaschist Group; BAGneiss Complex; $\mathrm{MG}$ - magmatic intrusions. Interval velocities are displayed on the right (from Batini et al., 1978).

low-angle normal faults (Lavecchia et al., 1984). These faults root in the Late Triassic evaporites, which are the main detachment level during this extensional event (Burdigalian-Langhian: Carmignani et al., 1995; Brunét et al., 2000). The second extensional event occurred between the Serravallian and the late Messinian and was characterised by normal faults sealed by Pliocene sediments (Mazzanti, 1967; Lazzarotto, 1967; Lazzarotto and Mazzanti, 1978). The third extensional event was characterised by formation of normal faults, which dissect Early-Middle Pliocene and Early Pleistocene sediments. These faults, generally NW-striking and NE-dipping, bound crustal blocks that have rotated southwestward (Baldi et al., 1994).

The Inner Northern Apennines were affected by widespread Late Miocene-Quaternary magmatism (see Fig. 1) deriving from mixing of crustal and mantle sources (Serri et al., 1993). In the Larderello area, boreholes encounter felsic dykes and granitoids at different depths, ranging in age between 3.8 and 2.25 Ma (Gianelli and Laurenzi, 2001). Magmatic fluids from these granitoids are considered to be the agents of the hydrothermal mineralization characterising many deep borehole samples (Gianelli, 1994).

Information on deeper structural levels derives from seismic reflection lines acquired for exploration for geothermal energy. The seismic lines show a clear distinction between a poorly reflective upper and a highly reflective mid-lower crust (Cameli et al., 1993). The top of the reflective crust is marked by a discontinuous reflector of high amplitude, referred to as the K-horizon (Batini et al., 1978), which has local bright spot features (Batini et al., 1985). These seismic features are also shown in regional reflection lines acquired for the study of the Northern Apennines deep crust (Pialli et al., 1998). The K-horizon, located regionally at a depth of $\sim 8-10 \mathrm{~km}$, shows a culmination in the Larderello area and appears to be related to a critical temperature (Liotta and Ranalli, 1999).

\section{Analysis of the reflection seismic lines}

In order to elucidate the geometry and the significance of the Pliocene-Present normal faults (latest extensional episode) and their relationship with the present brittle-ductile transition, several reflection seismic lines, acquired during the last 30 years for exploration purposes, were analysed (see location in Fig. 2). Their orientation and distribution allow us to investigate the entire geothermal area. Parameters for data acquisition and processing are described in Batini et al. $(1978,1985)$ and Cameli (1994). In the Larderello area, the surface geology is well known (Costantini, 2002; Sandrelli, 2002) and the borehole control is high (about 3 boreholes $/ \mathrm{km}^{2}$ ). The abundance of field and borehole data controls the geometry of geological bodies and structures from the surface down to about $3 \mathrm{~km}(\approx 1 \mathrm{~s}$ TWT). Our interpretation between 1 and $3 \mathrm{~s}$ TWT (i.e., the K-horizon depth range) is thus aided by the better-controlled upper part.

In the following subsections, the geological interpretation of two SSW-NNE migrated reflections lines (lines A and B in Fig. 2) is described. These lines are 
considered among the most significant - among the many we have analysed - to image the upper crustal features of the Larderello geothermal area. Conversion from time to depth has been based on vertical seismic profiles (well logs) and on P-velocity and Svelocity measurements (Batini and Nicolich, 1985; Batini et al., 1978; Tarquini et al., 1995; see Fig. 3 for interval velocities). As a check on the proposed interpretation, two lines parallel to the strike of sur- face normal faults (lines C and D in Fig. 2) are also examined.

\subsection{Line A}

The profile crosses the Serrazzano and the Pomarance Pliocene Basins (Figs. 2 and 4). The upper part of the crust is only sparsely reflective. Fairly good reflections are visible where the Ligurian Units lie on
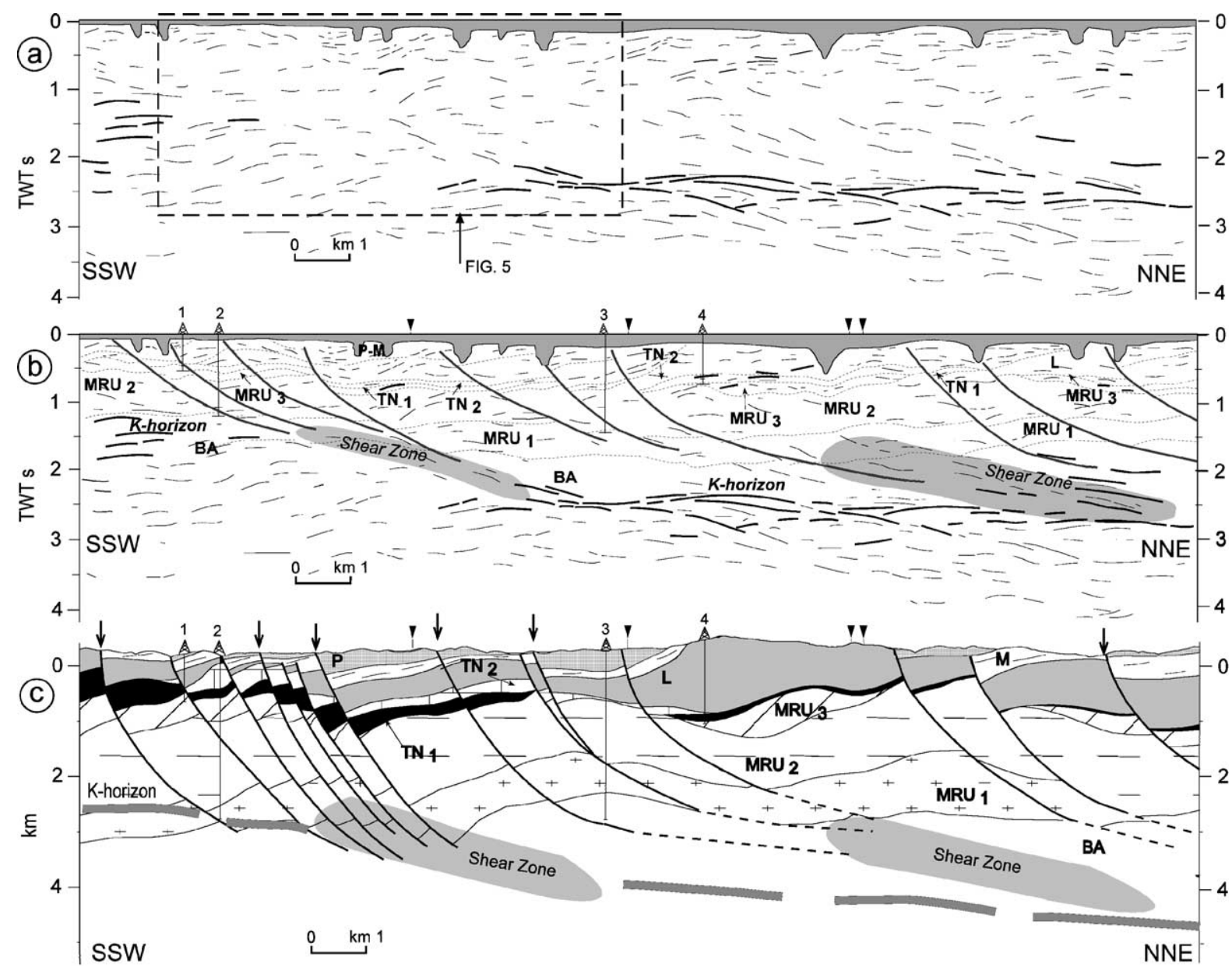

Fig. 4. (a) Line drawing of migrated line A. Datum plane is $200 \mathrm{~m}$ above sea level. The dashed rectangle shows the area displayed in Fig. 5. Reflections with high contrast of acoustic impedance are highlighted by thick lines. (b) Geological interpretation of the line constrained by field and borehole data. Dotted lines mark geological contacts; black triangles indicate intersection with other seismic lines. (c) Geological section obtained integrating borehole stratigraphies, field data, and the reflection seismics interpretation. Locations of outcropping normal faults are shown by black arrows. Key: P-Pliocene sediments; M-Miocene sediments; P-M: Pliocene and Miocene sediments; Tuscan Nappe (TN): $\mathrm{TN}_{2}$ - Early Miocene-Rhetic sequence; $\mathrm{TN}_{1}$ - Late Triassic evaporites; Monticiano-Roccastrada Unit (MRU): MRU $\mathrm{U}_{3}$-Mesozoic-Paleozoic Group; $\mathrm{MRU}_{2}$-Phyllite-Quartzitic Group; $\mathrm{MRU}_{1}$-Paleozoic Micaschist Group; BA—Gneiss Complex. 
the Late Triassic evaporites and on the carbonate sequence of the Tuscan Nappe. Also the Verrucano Group is characterised by a good reflectivity deriving from its duplex structure (Bertini et al., 1994). The line crosses NE-dipping listric normal faults related to the third extensional event. The geometry of these faults is well constrained by borehole and field data from the surface down to about $1 \mathrm{~s}$ TWT. The reflectivity of some of these faults is defined by weak NE-dipping reflections. As an example, Fig. 5 shows in detail a part of the profile. Where the downward continuation of faults can be seismically identified, it matches well borehole data and the surface geology (both boreholes and surface faults are shown in Figs. 4 and 5). The downward continuation of the normal faults, which bound the Serrazzano Pliocene Basin and tend to flatten with depth, corresponds to a loss of continuity in the K-horizon $(\approx 1.5 \mathrm{~s}$ TWT in Fig. 5), associated with E-dipping weak reflections. We interpret this feature as an extensional shear zone, displacing the K-horizon and associated with very high fluid pressure. Borehole 2 encounters a highly fractured
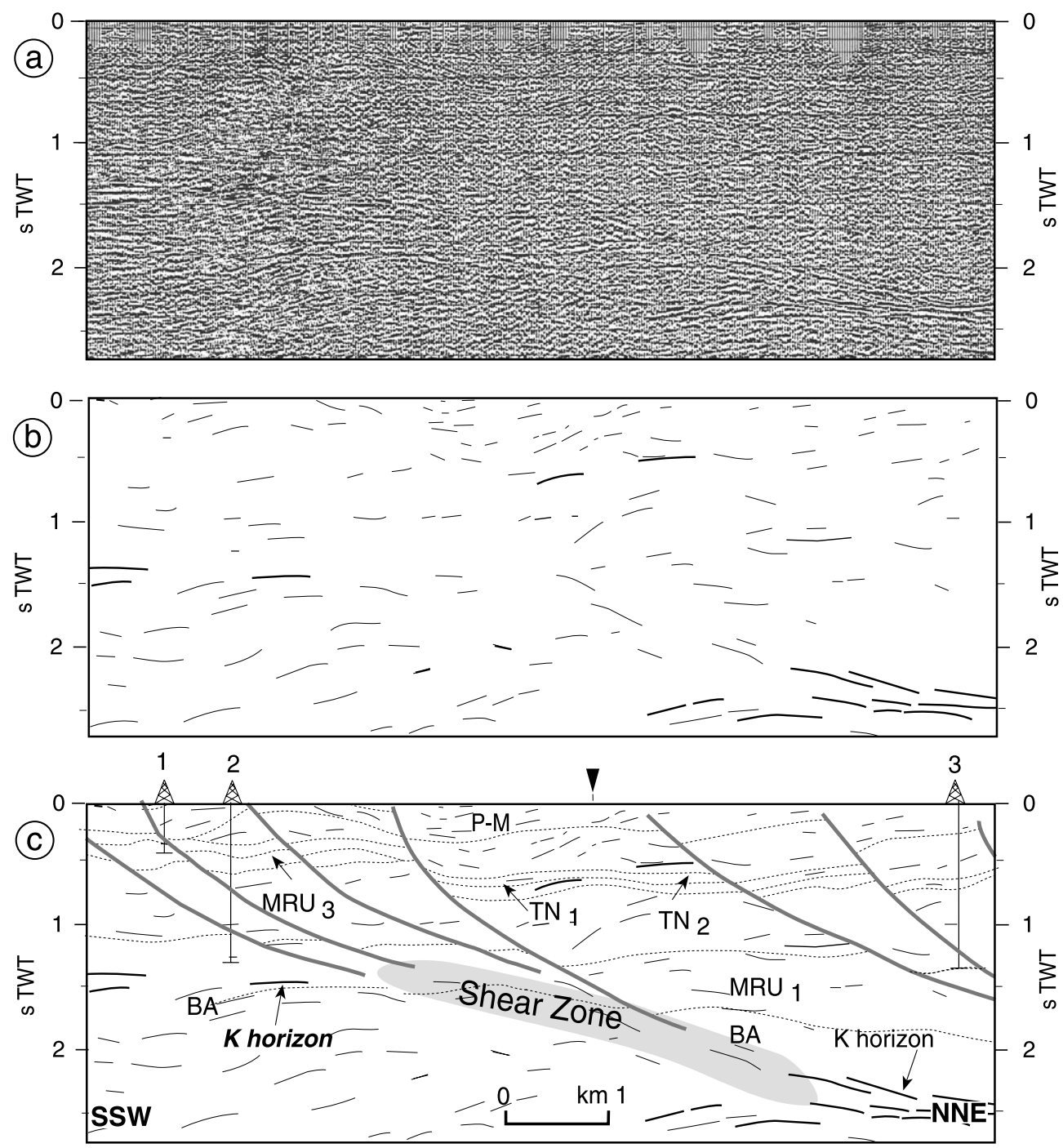

Fig. 5. (a) Detail of line A; (b) line drawing; and (c) geological interpretation. 
level, rich in hydrothermal minerals up to complete replacement of the original rock, at $\approx 2200 \mathrm{~m}$. Hydrothermal and contact metamorphism minerals were found in the bottomhole samples at $2930 \mathrm{~m}$ depth (Batini et al., 1985). An extremely high fluid pressure caused the blow-up of this borehole (Batini et al., 1985). In the central part of the section, the Khorizon becomes deeper $(\approx 2.2 \mathrm{~s}$ TWT $)$, assuming a clear bright spot feature (Batini et al., 1985), and a lozenge-shaped geometry characterises the reflectivity below it (Cameli et al., 1993). In the northern part of the section, weak reflections, gently dipping NE, are imaged above the K-horizon. These reflections are related to the normal faults of the central part of the Serrazzano Basin, coalescing in a northernmost shear zone.

\subsection{Line $B$}

The seismic line is approximately parallel to line A (Fig. 2). As in line A, the upper part is poorly reflective. However, the borehole data allow us to relate the more significant reflections to the Ligurian Units/Triassic evaporites boundary and to the imbricated structure of the Verrucano Group (Fig. 6). The downward increase in reflectivity is determined by the
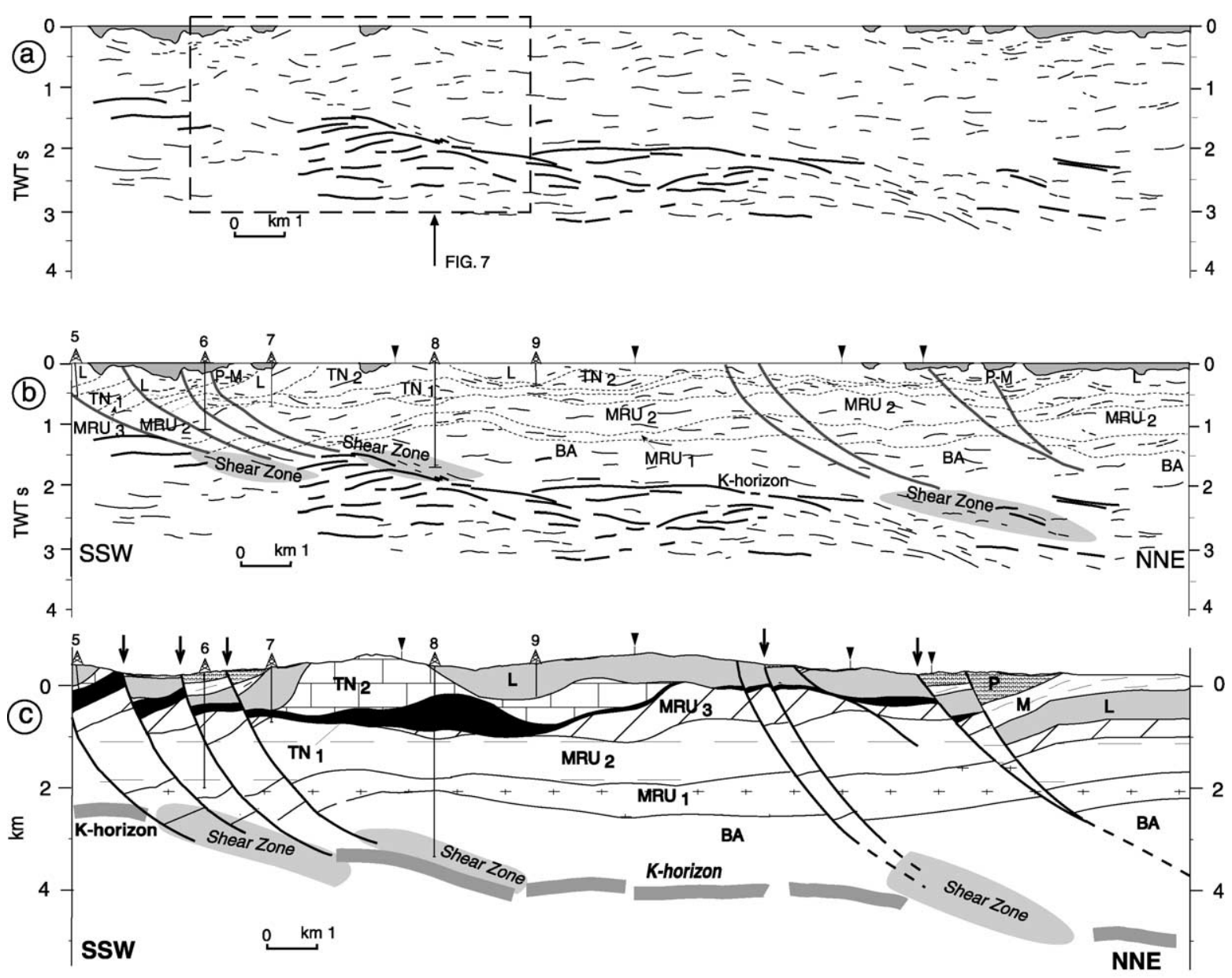

Fig. 6. (a) Line drawing of migrated line B. Datum plane is $200 \mathrm{~m}$ above sea level. The dashed rectangle indicates the area shown in the Fig. 7. (b) Geological interpretation of the line drawing. (c) Geological section obtained integrating borehole stratigraphies, field data, and the reflection seismics interpretation. Location of outcropping normal faults is shown by black arrows. 
appearance of the K-horizon, which is very well imaged in the central part of the section. Underneath the Serrazzano Basin, the K-horizon loses its characteristic image and a seismic facies with sparse reflectivity is present (Fig. 6; a detail is shown in Fig. 7). Where detectable, normal faults bounding the Serraz- zano Basin appear to root in this seismic facies. The $\mathrm{K}$-horizon is here offset from $1.2 \mathrm{~s}$ TWT to about $1.5 \mathrm{~s}$ TWT. Northwards, underneath borehole 8 , the Khorizon is imaged as a strong reflector, gently dipping to the north. Normal faults affecting the Serrazzano Basin are also interpreted to flatten in this dipping
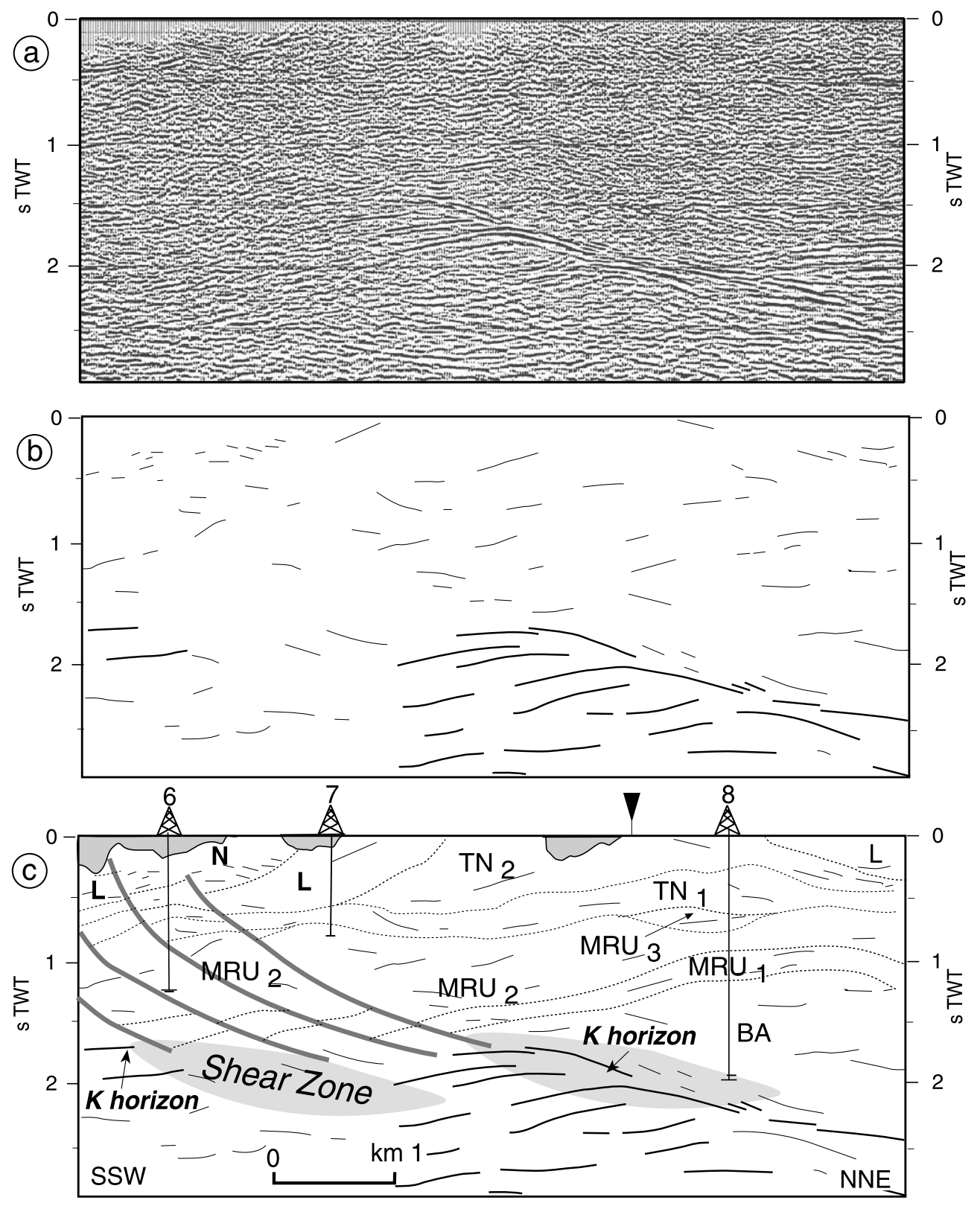

Fig. 7. (a) Detail of the line B; (b) line drawing; and (c) geological interpretation. 
reflector. Borehole 8 encounters fractured skarn rocks at bottomhole depth (around $3400 \mathrm{~m}$; Gianelli, 1994). In the central part of the section, the K-horizon is deeper (about $2.0 \mathrm{~s}$ TWT $\approx 5 \mathrm{~km}$ depth; Fig. 7). In the northeasternmost part of the line, the K-horizon and the reflections beneath lose their lateral continuity, and a seismic facies characterised by sparse reflections is again imaged. The normal faults of the Pomarance-Radicondoli Basin are interpreted to sole

(a)

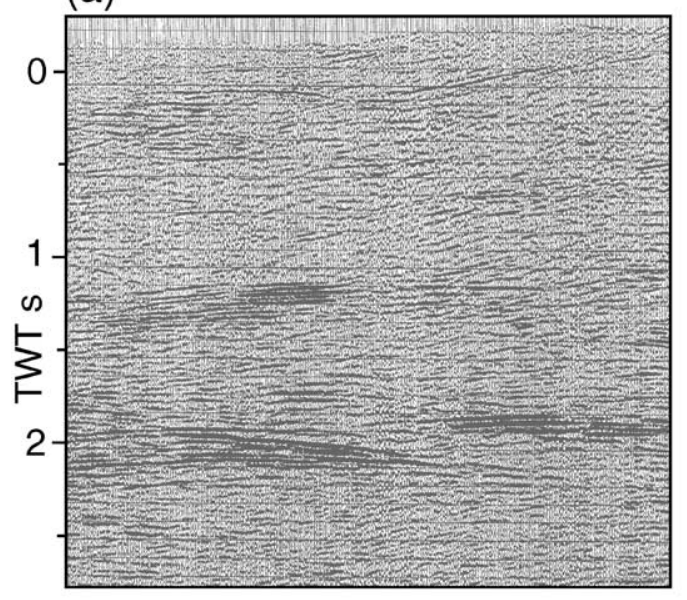

(c)

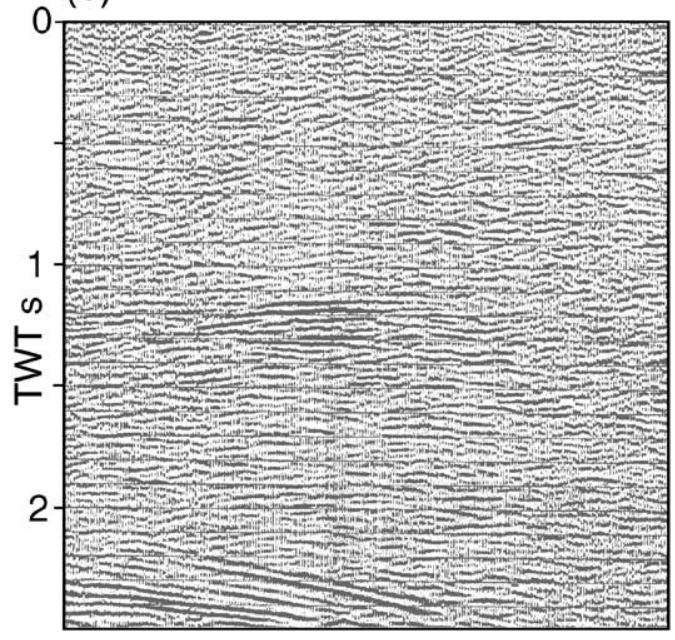

out here, in an extensional shear zone similar to the one discussed in line A.

\subsection{Seismic lines parallel to the strike of the faults}

Details of two reflection lines parallel to the strike of the surface faults (lines C and D in Fig. 2) are shown in Fig. 8. Clear subhorizontal reflections occur at $1.2-1.5 \mathrm{~s}$ TWT $(\approx 2.5-3.3 \mathrm{~km})$ and at about $2 \mathrm{~s}$

(b)
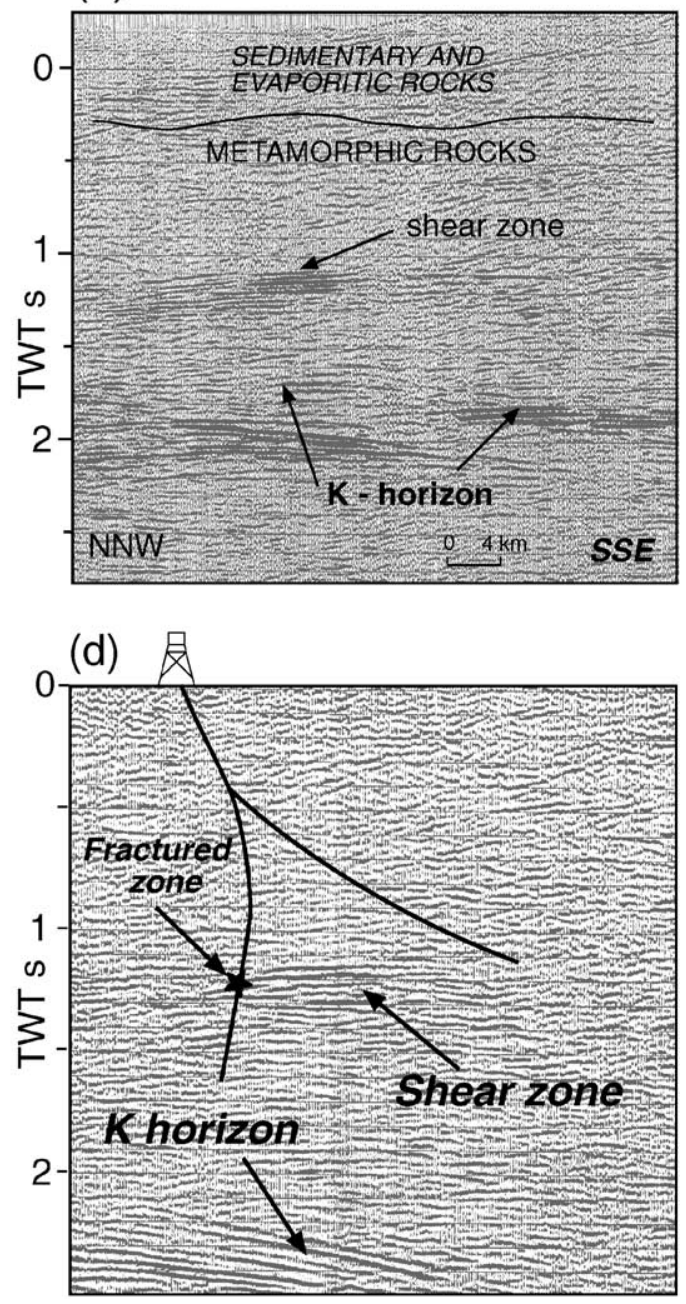

Fig. 8. ( $\mathrm{a}$ and $\mathrm{b}$ ) Part of line $\mathrm{C}$ and its geological interpretation. The sedimentary and evaporitic rocks belong to the Ligurian and Tuscan units whereas the metamorphic rocks are included in the Monticiano-Roccastrada Unit and in the Gneiss Complex. (c and d) Part of line D and its geological interpretation. Below the sedimentary cover, the borehole encounters a highly fractured zone in correspondence with the interpreted shear zone. 
TWT $(\approx 5 \mathrm{~km})$. The deeper ones are interpreted as the K-horizon while those at $1.2-1.5 \mathrm{~s}$ TWT correspond to the expected depth of the intersection of the extensional shear zones with the strike-parallel seismic lines.

\section{Discussion and conclusions}

Three major NE-dipping extensional shear zones can be recognised and mapped to depths of $\sim 5 \mathrm{~km}$ in the Larderello area (Fig. 9). Their surface expressions are, from west to east, the normal fault system affecting the western border of the Pliocene Serrazzano Basin, the Monterotondo normal fault system, and the normal fault system bounding the Pomarance-Radicondoli Basin (Figs. 2 and 9). Some of these faults are mineralised by mixed sulphides of hydrothermal origin linked to the Pliocene-Quaternary Tuscan magmatism (Arisi Rota et al., 1971).

The normal faults of the Serrazzano Basin dissect middle Pliocene sediments (Lazzarotto and Mazzanti, 1978) whereas those of the Radicondoli Basin affect early Pleistocene sediments (Mazzanti, 1967; Bossio et al., 1991). Therefore, a post-middle Pliocene and a post-early Pleistocene activity are proposed for the western and eastern extensional shear zones, respectively. The central shear zone and the correlated Monterotondo fault system are not time-constrained, but approximately coeval with the other two.

Recent boreholes encountered a felsic intrusive body in the footwall of the Cornate faults (Barelli et al., 2000). The structural position of this body is similar to that characterising other magmatic bodies of southern Tuscany such as the Elba Island granodiorite (Pertusati et al., 1993; Daniel and Jolivet, 1995) and the Giglio Island granodiorite (Lazzarotto et al., 1964; Rossetti et al., 1999). Structural models with extensional E-dipping shear zones in the northern Tyrrhenian and northern Apennines regions have been recently proposed by several authors (Jolivet et al., 1990; Storti, 1995; Decandia et al., 1998; Barchi et al., 1998; Acocella and Rossetti, 2002).

The geometry of listric normal faults in the Larderello geothermal field shows an interesting correlation with the K-horizon. All faults tend to flatten while approaching the K-horizon: but while some tend to sole out at this level, others - representing the main shear zones in the area-sole out in the lozengeshaped reflective zone below the K-horizon and are

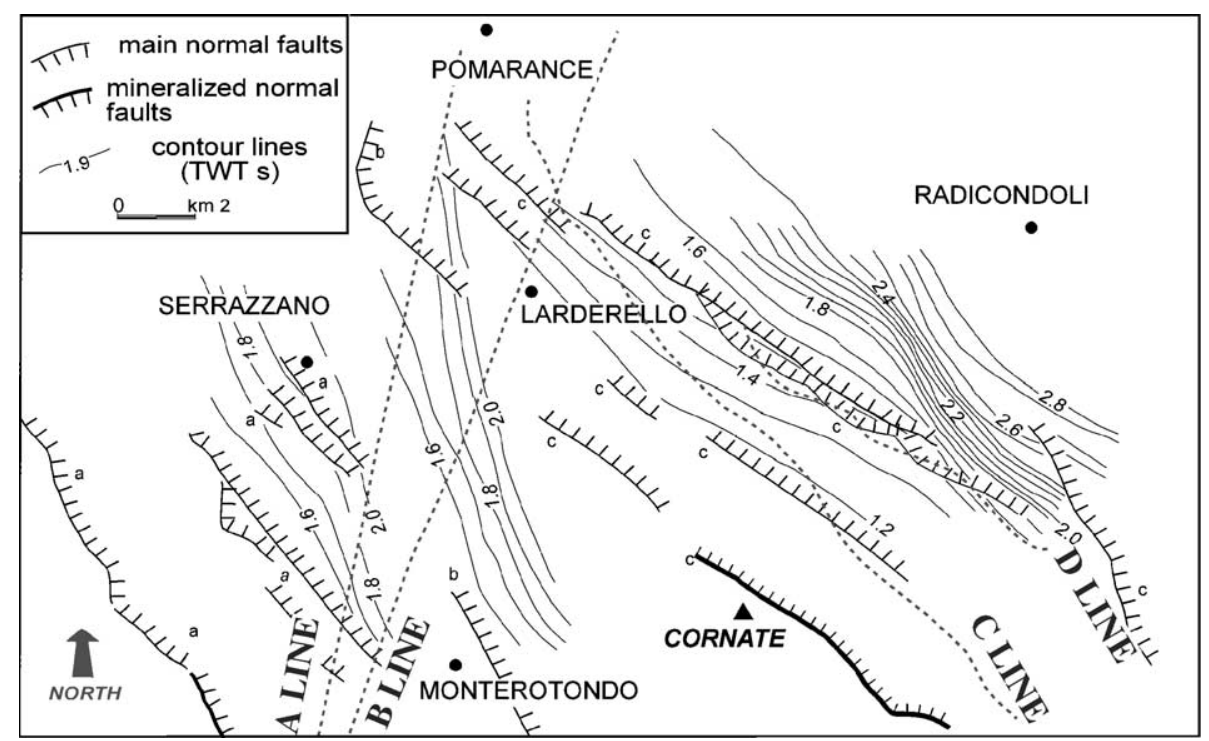

Fig. 9. Contour lines showing the predicted location of the three main extensional shear zones characterising the crustal structure of the Larderello area. Symbols a, b, and c denote normal faults related to the Serrazzano Basin, the Monterotondo zone, and the PomaranceRadicondoli Basin, respectively. 
associated with an apparent dislocation (change of depth) of the K-horizon and local loss of reflectivity. These differences derive from the transitional nature of the brittle-ductile transition. The origin of the reflectivity at the K-horizon and in the zone below has been discussed by several authors (see Gianelli et al., 1997 for a review). The occurrence of fluids can explain the observed high contrast in acoustic impedance (Batini and Nicolich, 1985; Batini et al., 1978, 1983; Cameli et al., 1993; Gianelli et al., 1997; Liotta and Ranalli, 1999). The nature of these fluids is a matter of speculation. Analyses of present-day geothermal fluids suggest that they are originated from mixing among dominant meteoric waters, products of water-rocks interaction, and fluids from deep magmas (Panichi et al., 1974; D’Amore and Bolognesi, 1994; Gianelli and Calore, 1996; Manzella et al., 1998).

If fluids are associated with the K-horizon, the local loss of reflectivity could be connected to the absence of fluids, which have migrated towards shallower levels along the shear zones identified in this paper. In this hypothesis, the K-horizon would be the "roof" of the level with very high fluid pressure, and the extensional shear zones would be the "way of escape" of fluids toward shallower levels.

Our interpretation of the relations among upper crustal structure, K-horizon, and hydrothermal fluid migration in the Larderello area is shown in Fig. 10. The upper crustal structure is characterised by NEdipping extensional shear zones whose activity is post-Middle Pliocene. These sole out in a subhor- izontal top-to-NE shear zone, located at the brittleductile transition and marked at the top by the Khorizon. As the brittle-ductile transition is transitional and spans a few kilometres of depth, part of the crustal shear is taken up in a ductile manner below the Khorizon, which accounts for the increase in reflectivity observed in this depth range.

The presence of three main shear zones and their link with mineralised normal faults points to paths where circulation of hydrothermal fluids is concentrated. The decrease of reflectivity above the top of the brittle-ductile transition is probably related to the absence of high fluid pressures as fluids escaped along the shear zones. If this hypothesis is correct, more detailed reflection seismic surveys are a powerful tool in order to recognise possible hydrological pathways in geothermal systems subject to extensional stress fields.

\section{Acknowledgements}

This work has been supported by COFIN2000 research grants (Italian Ministry of University and Scientific Research and Technology, MURST). G.R. was also supported by the Natural Sciences and Engineering Research Council of Canada (NSERC). The ENEL Green Power Agency allowed us to consult their geological and geophysical archive and to publish the data presented in this paper. Giusy Lavecchia and two anonymous referees are thanked for their constructive remarks and critical reading of a previous version of the manuscript.

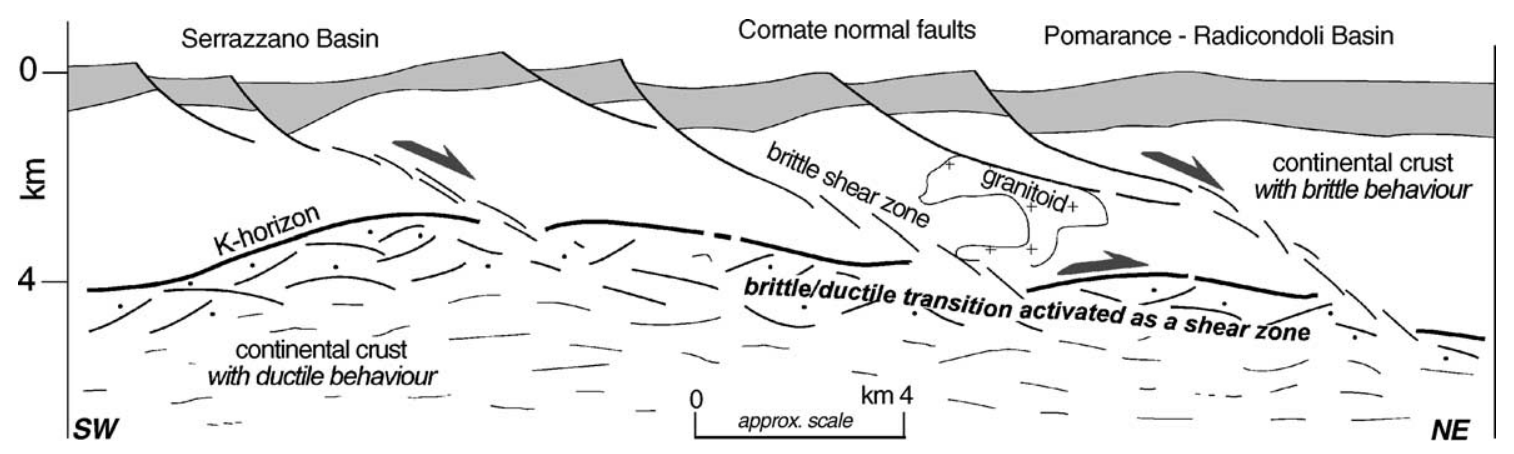

Fig. 10. Geological interpretation of the Larderello geothermal area. The main extensional shear zones and the top of the brittle-ductile transition are shown. The brittle-ductile transition is activated as a top-to-NE shear zone. Light grey: sedimentary cover. Arrows indicate the sense of shear. 


\section{References}

Acocella, V., Rossetti, F., 2002. The role of extensional tectonics at different crustal levels on granite ascent and emplacement: an example from Tuscany (Italy). Tectonophysics 354, 71-83.

Arisi Rota, F., Brondi, A., Dessau, G., Franzini, M., Monte Amiata, S.P.A., del Sele, S.M., Stea, B., Vighi, L., 1971. I Giacimenti minerari. Rend. Soc. Ital. Mineral. Petrol. 27, 357-544.

Baldi, P., Bertini, G., Cameli, G.M., Decandia, F.A., Dini, I., Lazzarotto, A., Liotta, D., 1994. La tettonica distensiva post-collisionale nell'area geotermica di Larderello (Toscana meridionale). Studi Geol. Camerti 1, 183-193.

Bally, A.W., Bernoulli, D., Davis, G.A., Montadert, L., 1981. Listric normal faults. Oceanologica Acta, No Sp., Proceedings $26^{\text {afth }}$ International Geological Congress, Geology of Continental Margin Symposium, Paris, July 7-17, 1980, pp. 87-101.

Barchi, M., Minelli, G., Pialli, G., 1998. The CROP 03 profile: a synthesis of results on deep structures of the Northern Apennines. Mem. Soc. Geol. Ital. 52, 383-400.

Barelli, A., Bertini, G., Buonasorte, G., Capetti, G., Fiordelisi, A., 2000. Recent deep exploration results at the margins of the Larderello Travale geothermal system. Proceedings World Geothermal Congress 2000, Kyushu, Tohoku, Japan, May 28-June 10, pp. $965-970$.

Batini, F., Nicolich, R., 1985. P and S reflection seismic profiling and well logging in the Travale geothermal field. Geothermics 14, 731-747.

Batini, F., Burgassi, P.D., Cameli, G.M., Nicolich, R., Squarci, P., 1978. Contribution to the study of the deep lithospheric profiles: deep reflecting horizons in Larderello-Travale Geothermal field. Mem. Soc. Geol. Ital. 19, 477-484.

Batini, F., Bertini, G., Giannelli, G., Pandeli, E., Puxeddu, M., 1983. Deep structure of the Larderello geothermal field: contribution from recent geophysical and geological data. Mem. Soc. Geol. Ital. 5, 219-235.

Batini, F., Bertini, G., Giannelli, G., Pandeli, E., Puxeddu, M., Villa, I., 1985. Deep structure, age and evolution of the Larderello-Travale geothermal field. Geotherm. Res., Commun. Trans. $9,1-7$.

Bertini, G., Cameli, G.M., Costantini, A., Decandia, F.A., Di Filippo, M., Dini, I., Elter, F.M., Lazzarotto, A., Liotta, D., Pandeli, E., Sandrelli, F., Toro, B., 1991. Struttura geologica fra i monti di Campiglia e Rapolano Terme (Toscana meridionale): stato attuale delle conoscenze e problematiche. Studi Geol. Camerti 1, 155-178.

Bertini, G., Bertozzi, A., Dini, I., Santini, M., Tosi, F., Valenti, P., 1994. Sondaggio stratigrafico Massa 2. Studi Geol. Camerti 1, 93-96.

Blundell, D.J., 1990. Seismic images of continental lithosphere. J. Geol. Soc. (Lond.) 147, 895-913.

Bossio, A., Mazzanti, R., Mazzei, R., Salvatorini, G., Sandrelli, F., 1991. Il Pliocene dell'area di Pomarance (Pisa). Atti Soc. Tosc. Nat. Mem. 98, 1-98.

Brunet, C., Monié, P., Jolivet, L., Cadet, J.P., 2000. Migration of compression and extension in the Tyrrhenian Sea, insights from ${ }^{40} \mathrm{Ar} /{ }^{39} \mathrm{Ar}$ ages on micas along a transect from Corsica to Tuscany. Tectonophysics $321,127-155$.
Cameli, G.M., 1994. Indagine sulla tecnica di acquisizione sismica della linea CROP 18. Studi Geol. Camerti 1, 13-17.

Cameli, G.M., Dini, I., Liotta, D., 1993. Upper crustal structure of the Larderello geothermal field as a feature of post-collisional extensional tectonics (Southern Tuscany, Italy). Tectonophysics 224, 413-423.

Cameli, G.M., Dini, I., Liotta, D., 1998. Brittle/ductile boundary from seismic reflection lines of southern Tuscany (Northern Apennines, Italy). Mem. Soc. Geol. Ital. 52, 153-163.

Cameli, G.M., Ceccarelli, A., Dini, I., Mazzotti, A., 2000. Contribution of the seismic reflection method to the location of deep fractured levels in the geothermal fields of Southern Tuscany (central Italy). Proceedings World Geothermal Congress 2000, Kyushu, Tohoku, Japan, May 28-June 10, pp. 1025-1029.

Carmignani, L., Kligfield, R., 1990. Crustal extension in the northern Apennines: the transition from compression to extension in the Alpi Apuane core complex. Tectonics 9, 1275-1303.

Carmignani, L., Decandia, F.A., Disperati, L., Fantozzi, P.L., Lazzarotto, A., Liotta, D., Oggiano, G., 1995. Relationships between the Sardinia-Corsica-Provençal Domain and the Northern Apennines. Terranova 7, 128-137.

Costantini, A. (Ed.), 2002. Foglio 306-Massa Marittima. Carta Geologica d'Italia 1:50000. Servizio Geologico Italiano, Rome.

Dallmeyer, R.D., Liotta, D., 1998. Extension, uplift of rocks and cooling ages in thinned crustal provinces: the Larderello geothermal area (Inner Northern Apennines, Italy). Geol. Mag. 135, $193-202$.

D’Amore, F., Bolognesi, L., 1994. Isotopic evidence for a magmatic contribution to the fluids of the geothermal systems of the Larderello and the Geysers. Geothermics 23, 21-32.

Daniel, J.M., Jolivet, L., 1995. Detachment faults and pluton emplacement: Elba Island (Tyrrhenian Sea). Bull. Soc. Geol. Fr. $166,341-354$.

Decandia, F.A., Lazzarotto, A., Liotta, D., Cernobori, L., Nicolich, R., 1998. The Crop 03 traverse: insights on post-collisional evolution of northern Apennines. Mem. Soc. Geol. Ital. 52, 427-439.

Elter, F.M., Pandeli, E., 1990. Alpine and Hercynian orogenic phases in the basement rocks of the Northern Apennines (Larderello geothermal field, Southern Tuscany, Italy). Eclogae Geol. Helv. 83, 241-264.

Franceschini, F., 1994. "Larderello plutono-metamorphic core complex": metamorfismo regionale ercinico di bassa pressione o metamorfismo di contatto plio-quaternario? Studi Geol. Camerti $1,113-128$.

Gianelli, G., 1994. Ipotesi di un modello di crosta superiore per le aree geotermiche toscane. Studi Geol. Camerti 1, 195-200.

Gianelli, G., Calore, C., 1996. Models for the origin of carbon dioxide in the Larderello geothermal field. Boll. Soc. Geol. It. $115,75-84$.

Gianelli, G., Laurenzi, M.A., 2001. Age and cooling rate of the geothermal system of Larderello. Geotherm. Resour. Counc. Trans. 25, 731-735.

Gianelli, G., Manzella, A., Puxeddu, M., 1997. Crustal models of the geothermal areas of Southern Tuscany. Tectonophysics 281, $221-239$.

Hamilton, W., 1987. Crustal extension in Basin and Range Prov- 
ince, southwestern United States. In: Coward, M.P., et al. (Eds.), Continental Extensional Tectonics. Geol. Soc. Spec. Publ., vol. 28, pp. $155-176$.

Jolivet, L., Dubois, R., Fournier, M., Goffé, B., Michard, A., Jourdan, C., 1990. Ductile extension in the Alpine Corsica. Geology 18, 1007-1010.

Klemperer, S., 1987. A relation between continental heat flow and the seismic reflectivity of the lower crust. J. Geophys. 61, 1-11.

Klemperer, S., Hobbs, R., 1991. The BIRPS Atlas. Cambridge Univ. Press, Cambridge.

Kusznir, N.J., Park, R.G., 1987. The extensional strength of the continental lithosphere: its dependence on geothermal gradient, and crustal composition and thickness. In: Coward, R.G., et al. (Eds.), Continental Extensional Tectonics. Geol. Soc. Spec. Publ., vol. 28, pp. 35-52.

Lavecchia, G., Minelli, G., Pialli, G., 1984. L’ Appennino umbromarchigiano: tettonica distensiva ed ipotesi di sismogenesi. Boll. Soc. Geol. Ital. 103, 467-476.

Lazzarotto, A., 1967. Geologia della zona compresa fra l' alta Valle del Fiume Cornia ed il Torrente Pavone (Prov. di Pisa e Grosseto). Mem. Soc. Geol. Ital. 6, 151-197.

Lazzarotto, A., Mazzanti, R., 1978. Geologia dell' alta Val di Cecina. Boll. Soc. Geol. Ital. 95, 1365-1487.

Lazzarotto, A., Mazzanti, R., Mazzoncini, F., 1964. Geologia del promontorio Argentario (Grosseto) e del promontorio del Franco (Isola del Giglio-Grosseto). Boll. Soc. Geol. Ital. 83, 1-125.

Liotta, D., Ranalli, G., 1999. Correlation between seismic reflectivity and rheology in extended lithosphere: southern Tuscany, Inner Northern Apennines, Italy. Tectonophysics 315, 109-122.

Manzella, A., Ruggieri, G., Gianelli, G., Puxeddu, M., 1998. Plutonic-geothermal systems of southern Tuscany: a review of the crustal models. Mem. Soc. Geol. It. 52, 283-294.

Mayer, G., Mai, P.M., Plenefisch, T., Echtler, H., Lüschen, E., Wehrle, V., Müller, B., Bonjer, K.P., Prodehl, C., Fuchs, K., 1997. The deep crust of the Southern Rhine Graben: reflectivity and seismicity as images of dynamic processes. Tectonophysics 275, 15-40.

Mazzanti, R., 1967. Geologia della zona di Pomarance-Larderello (Prov. di Pisa). Mem. Soc. Geol. Ital. 5, 105-138.

McCarthy, J., Thompson, G.A., 1988. Seismic imaging of extended crust with emphasis on the western United States. Geol. Soc. Am. Bull. 100, 1361-1374.
Mongelli, F., Zito, G., Ciaranfi, N., Pieri, P., 1989. Interpretation of heat flow density of the Apennine chain, Italy. Tectonophysics 164, 267-280.

Panichi, C., Celati, R., Noto, P., Squarci, P., Taffi, L., Tongiorgi, E., 1974. Oxygen and hydrogen isotope studies of the Larderello (Italy) geothermal system. Isotope Techniques in Groundwater Hydrology. Int. Atomic Energy Agency (SM-182/27) 2, 3-28.

Pertusati, P., Raggi, G., Ricci, C.A., Duranti, S., Palmeri, R., 1993. Evoluzione post-collisionale dell'Elba centro-orientale. Mem. Soc. Geol. Ital. 49, 297-312.

Pialli, G.P., Barchi, G., Minelli, G. (Eds.), 1998. Results of the Crop 03 deep seismic reflection profile. Mem. Soc. Geol. Ital., vol. 52. $657 \mathrm{pp}$.

Ranalli, G., 1995. Rheology of the Earth, 2nd ed. Chapman and Hall, London.

Ranalli, G., Murphy, D.C., 1987. Rheological stratification of the lithosphere. Tectonophysics 133, 281-295.

Rossetti, F., Faccenna, C., Jolivet, L., Funiciello, R., Tecce, F., Brunét, C., 1999. Syn-versus post-orogenic extension: the case study of Giglio Island (Northern Tyrrhenian Sea, Italy). Tectonophysics 304, 71-93.

Sandrelli, F. (Ed.), 2002. Foglio 295-Pomarance. Carta Geologica d'Italia 1:50000. Servizio Geologico Italiano, Rome.

Serri, G., Innocenti, F., Manetti, P., 1993. Geochemical and petrological evidence of the subduction of delaminated Adriatic continental lithosphere in the genesis of the Neogene-Quaternary magmatism of central Italy. Tectonophysics 223, 117-147.

Shelton, J.W., 1984. Listric normal faults: an illustrated summary. Am. Assoc. Pet. Geol. Bull. 68, 801-815.

Storti, F., 1995. Tectonics of the Punta Bianca promontory: insights for the evolution of the Northern Apennines-Northern Tyrrhenian Sea Basin. Tectonics 14, 832-847.

Tarquini, B., Cameli, M., Donati, C., Martin, R.J., 1995. The effect of pressure, temperature, and lithology on seismic wave velocities for rocks from the Larderello geothermal field. Proceedings of the 1995 World geothermics Congress, Florence, Italy, May $18-31$, pp. $813-815$.

Villa, I., Puxeddu, M., 1994. Geochronology of the Larderello geothermal field: new data and the "closure temperature" issue. Contrib. Mineral. Petrol. 115, 415-426. 